\title{
FEATURES OF FORMATION OF BASIC PROFESSIONAL EDUCATIONAL PROGRAMS BASED ON FGOS VO 3 ++
}

\author{
Yuliya Netrebina ${ }^{1}$, Nadezhda Khakhulina ${ }^{2}$, Valery Barinov ${ }^{3}$, Boris Popov ${ }^{4}$ \\ ${ }^{1}$ Candidate of Geographical Sciences, assistant Professor, Voronezh State Technical University, \\ 20 years of October street, 84,Voronezh, Russia, E-mail: juliya_net@mail.ru \\ ${ }^{2}$ Candidate of technical Sciences, associate Professor Voronezh State Technical University, 20 \\ years of October street, 84,Voronezh, Russia, E-mail: hahulina@mail.ru \\ ${ }^{3}$ Doctor of Technical Sciences, Associate Professor, Voronezh State Technical University, 20 \\ years of October street, 84,Voronezh, Russia, E-mail: kafedravgasu@yandex.ru \\ ${ }^{4}$ Candidate of Agricultural Sciences, Associate Professor, Voronezh State Technical University, 20 \\ years of October street, 84,Voronezh, Russia, E-mail: b.p.geo@yandex.ru
}

\begin{abstract}
The transition to the updated FSES HE $3++$ is carried out with certain difficulties associated with the delay in the approval of standards in many areas of training, as well as the lack of exemplary educational programs. However, a team of authors, independently, without waiting for the release of model educational programs, develops professional competencies, indicators of achievement of competencies, knowledge, skills, possession and, accordingly, a list of disciplines that form these competencies. This article is devoted to the analysis of the educational standard of the Federal State Educational Standard of Higher Education $3++$ of the direction "Land management and cadastres". In conditions of some uncertainty associated with the delay in approval of individual FSES $3++$, professional standards, exemplary basic professional educational programs, educational organizations are given the opportunity to independently decide approaches to achieving universal, general professional competencies and the formulation of achievements of professional competencies by graduates.
\end{abstract}

Keywords: FSES VO $3++$, competencies, indicators of professional competencies, professional standards.

\section{INTRODUCTION}

For successful personal development in the era of global competition and rapid changes in society, it is important to rely on education. In this regard, there is a constant change in the requirements that are mandatory in the implementation of educational programs of higher education. The change in standards is not just a change in design, it is a lot of work to improve the approach to obtaining a new specialist with the requirements stated in the Federal State Educational Standard and educational programs of universities. In August 2020, new educational standards of the Federal State Educational Standard of Higher Education 3 ++ were approved in a number of areas of bachelor's and master's degrees. The new standards do not cancel the effect of the previous ones, as was the case with the adoption of the Federal State Educational Standard of Higher Education 3+, and allow the training of students adopted before the entry into force of a specific educational standard. But the admissions campaign in 2021 must be carried out by educational organizations according to new standards.

What caused the change in educational standards? According to the Federal Law "On Education in the Russian Federation", the formation of the requirements of the Federal State Educational Standard of Higher Education for the results of mastering basic professional educational programs (OBEP) should be carried out on the basis of appropriate professional standards in order to form the necessary professional competencies in graduates [1]. Numerous studies of the authors are devoted to this issue [2-8]. In accordance with federal 
standards, educational and methodological associations should develop exemplary educational programs that universities can take as a basis for their educational programs, however, as practice shows, exemplary educational programs have not appeared. The main purpose of the study is to analyze the updated standard of the direction 03.21.02 Land management and cadastres.

\section{METHODOLOGY}

The theoretical research methods used in the work consisted in the analysis of the main regulatory documents in the field of education, Federal state educational standards for higher education, educational and methodological support and educational programs of various directions, which were updated earlier. Also, the work used predictive methods in the formation of the main professional educational programs of higher education, curricula, planning the educational process and obtaining, as a result, the qualifications of an employee.

\section{DISCUSSION}

As already noted, the updated standards in all areas require the coordination of educational programs with professional standards in terms of requirements for the training of graduates. The introduction of these standards force educational organizations to interact more closely with employers, to take into account the demands of the labor market, to be more flexible in the formation of educational programs, taking into account regional characteristics. Educational programs developed according to the updated Federal State Educational Standard must be based on professional standards posted on the specialized website of the Ministry of Labor and Social Protection of the Russian Federation. A professional standard is a detailed description of the level of performance of a specific type of professional activity, expressed in terms of competencies [9].

\section{RESULTS}

Areas of professional activity stated in the standard 21.03.02. "Land management and cadastres", in which graduates of this direction can work, are: education and science, finance and economics, architecture, design, geodesy, topography and design, rocket and space industry, as well as cross-cutting professional activities in industry. The broadest area of professional activity presented in the updated FSES, in our opinion, is architecture, design, geodesy and topography, because it involves the sphere of maintaining and developing spatial data for state cadastral registration, preparation and planning of field work on engineering and geodetic surveys and their office processing for land management and cadastres, carrying out work on the survey and monitoring of objects of urban planning activities, office processing of research results, drawing up reports, design products and technical passports for cadastral activities; collection and systematization of information for the development and formation of a set of urban planning documentation [10]. However, the standard allows the use of other areas of professional activity. According to the Federal State Educational Standard, the educational organization determines the tasks of professional activity (from those stated in the standard) and the focus of the program. Federal State Educational Standard of Higher Education $3++$ instead of the usual general cultural competences, contains universal competences linked to categories. These categories take into account important directions of personality development, ensuring successful human activity not only in professional but also in social spheres.

As noted by the authors [11-17, 21], universal competences are of a supra-subject nature, their formation is carried out within the framework of various forms of organization of the educational process, regardless of the specific academic discipline of the educational program, throughout the entire period of study. Considering that the nature of universal competencies is activity-based, and not knowledgeable, the first place in the educational process of higher education is not informing the student, but the formation of skills to solve problems arising in situations of cognition and explanation of the phenomena of reality, the development of modern techniques and technologies, the inclusion in a situation of professional and supraprofessional interaction. The next type of competence presented in the Federal State Educational Standard of Higher Education $3++$ is general professional competence. They are also categorized as: use of tools and equipment, research, decision making and others. All general professional competencies must be included in the educational program, thus forming a mandatory part of the program. Professional competencies should be formed by the educational organization independently, taking into account the requirements of professional standards that correspond to the professional activities of graduates from the register of professional standards. Also, an educational organization has the right to include professional competencies formulated on the basis of an analysis of the requirements for professional competencies for graduates in the labor market, generalization of domestic and foreign experience, consultations with leading employers, associations of employers in the industry in which graduates are in demand [10]. 
In accordance with the competencies, the educational organization establishes indicators of the achievement of competence. At the same time, indicators of achievement of competencies, as it was assumed, should have been determined in exemplary educational programs, as well as knowledge of skills and possession and, accordingly, discipline. But, since these programs did not come out, universities were forced to develop for themselves indicators of achievement of competencies in universal and general professional competencies. Indicators are the building blocks leading to competence, in which activity is manifested. Competency indicators should be characterized by such qualities as sufficiency, measurability, clarity of wording and continuity across educational levels [16]. The developers of the main professional educational programs independently carry out the decomposition of the educational result in the process of developing a competency matrix that reflects the logic of the formation of competencies. To optimize this type of activity, one should understand the essence and content of decomposition elements in order to correctly form the individual elements of the educational program (discipline, practice). As for the use of the professional standards proposed by the Federal State Educational Standard of Higher Education $3++21.03 .02$ "Land management and cadastres", they do not fully characterize the professional activity of the graduate, they do not cover all professional trajectories of graduates. Thus, the list of professional standards corresponding to the professional activities of graduates does not include the professional standard "Land Surveyor" [18], "Specialist in determining the cadastral value" [19] and some others. Currently, a significant professional activity in the field of cadastres is the determination of the cadastral value of real estate objects, information about which is included in the unified state register of real estate, therefore, it was important for our educational program to include the labor functions of this professional standard. In addition, a demanded procedure is the contestation of the cadastral value of a land plot, so the specialist must be prepared for the market valuation of real estate. The labor functions of a specialist are already related to another professional standard - "Specialist in appraisal activities" [20]. Both of these professional standards were not included in the list of proposed FGOS VO 3 ++ standards. Occupational standards contain generalized work functions that correspond to a certain level of education. Therefore, when choosing labor functions, it is important to take into account the level of qualifications of a specialist, for which you can prepare with the means available in the educational process in a specific educational program.

\section{CONCLUSION}

When formulating professional competencies, it is proposed: 1) Analyze the list of labor functions, professional standards, selected for the development of a specific educational program; 2) Select the most significant labor functions that meet the necessary qualifications; 3) Formulate a list of professional competencies based on the selected units of the professional standard and qualification requirements for them. 4) Indicators of professional competencies can be presented in the form of learning outcomes, or in the form of specific actions performed by a graduate who has mastered this competence (they should disclose a labor action, but not coincide with it). It is through competencies, understood as the ability of a person to apply knowledge, skills and practical experience in familiar and unfamiliar work situations, that the educational program should prepare a competent versatile specialist who is able to introduce new technological solutions, manage projects, be creative, ready for teamwork.

\section{REFERENCE LIST}

1. Federal Law "On Education in the Russian Federation" dated December 29, 2012 N 273-FZ (last edition) // http://www.consultant.ru/document/cons_doc_LAW_140174/. (in Russian).

2. Altbach Ph.G., Reisberg L., Rumbley L.E. (2009) Trends in Global Higher Education: Tracking an Academic Revolution. A Report Prepared for the UNESCO 2009 World Conference on Higher Education. Paris, UNESCO. 247 p. (in English)

3. Kelchevskaya N.R., Shirinkina E.V. (2018) Integration of educational and professional standards in the context of reform: problems and solutions. University Management: Practice and Analysis. \# 1. Pp. 1625. (in Russian).

4. Pilipenko S.A., Zhidkov A.A., Karavaeva E.V., Serova A.V. (2016) Conjugation of fgos and professional standards: identified problems, possible approaches, recommendations for updating. Higher education in Russia. No. 6 (202). Pp. 5-15. (in Russian).

5. Karavaeva E.V. (2017) Higher education qualifications and vocational qualifications: "interfacing with 
tension". Higher education in Russia. No. 12 (218). Pp. 5-12. (in Russian).

6. Belotserkovsky A.V. (2015) On the issue of harmonizing educational and professional standards. Higher education in Russia. No. 6. Pp. 26-31. (in Russian).

7. Senashenko V.S. (2015) On the ratio of professional standards and federal state educational standards for higher education. Higher education in Russia. No. 6. Pp. 31-36. (in Russian).

8. Karavaeva E.V. (2016) Will the emerging national qualifications system in Russia contribute to the harmonization of the Russian higher education system with world educational systems and improve the quality of training? Altai - Asia 2016. Eurasian educational space - new challenges and best practices. Pp. 29-33. (in Russian).

9. Labor Code of the Russian Federation "from 30.12.2001 N 197-FZ (as amended on 09.11.2020) // http://www.consultant.ru/document/cons doc LAW 34683/. (in Russian).

10.Federal state educational standard of higher education - bachelor's degree in the direction of training 03.21.02 Land management and cadastres // http://fgosvo.ru/uploadfiles/FGOS\%20VO\%203++/Bak/21.03.02.pdf. (in Russian).

11. Mishin I. N. (2018) Critical assessment of the formation of the list of competencies in the Federal State Educational Standard of Higher Education $3++$. Higher education in Russia. No. 4. Pp. 66-75. (in Russian).

12.Ignatiev V.P., Alekseeva T.E., Bogushevich I.P. (2019) Basic principles of updating federal state educational standards of higher education Modern problems of science and education. No. 6. 56 p. (in Russian).

13.Pilipenko S. A. (2016) Conjugation of the Federal State Educational Standard and professional standards: identified problems, possible approaches, recommendations for updating. Higher education in Russia. No. 6. Pp. 5-15. (in Russian).

14.Kazakova E. I., Tarkhanova I. Yu. (2018) Assessment of universal competencies of students in the development of educational programs. Pedagogy. No. 9. Pp. 79 - 84. (in Russian).

15.Sosnin N. V. (2014) On the problem of translating competencies into the content of training. Higher education in Russia. No. 12. Pp. 64-71. (in Russian).

16. Bershadskaya M, Chepurenko A., Serova A., Zima E. (2018) Indicators of Achieving the Competencies of Graduates and the Quality of Mass Higher Education. Toronto. Abstracts of the XIX World Congress of Sociology «Power, Violence and Justice: Reflections, Responses and Responsibilities». Pp. 38-55. (in English)

17. Kruglyakova G.V. (2018) Approaches to the development of assessment tools for formed competencies based on the FGOS $3++$ standard. Tatishchev Readings: Actual Problems of Science and Practice: Materials of the XV International Scientific and Practical Conference. No. 3. Pp. 83-89. (in Russian).

18.Professional standard Land surveyor [Electronic resource]. - URL: http://www.consultant.ru/document/cons doc LAW 298818/. (in Russian).

19.Professional standard Specialist in determining the cadastral value [Electronic resource]. - URL: http://www.consultant.ru/document/cons_doc_LAW_363569/. 1 (in Russian).

20.Professional standard Specialist in appraisal activity [Electronic resource] .- URL: http://www.consultant.ru/document/cons doc LAW 317389/. (in Russian).

21.Khakhulina N.B. (2019) Environmental engineering in educational and design activities. Khakhulina N.B., Ivanov B.I. Environmental models and technologies (regional aspect). No. 1 (8). Pp. 26-. (in Russian). 